\title{
HORMONAL STATUS AND REGULATION OF GLYCEMIA IN NEONATAL CALVES DURING THE FIRST HOURS OF POSTNATAL LIFE
}

\author{
KIROVSKI DANIJELA*, LAZAREVIĆ $\mathrm{M}^{*}$, STOJIĆ $\mathrm{V}^{*}$, ŠAMANC $\mathrm{H}^{*}$, VUJANAC $\mathrm{I}^{*}$, NEDIĆ OLGICA** \\ and MASNIKOSA ROMANA** \\ *University of Belgrade, Faculty of Veterinary Medicine, Serbia \\ **Institute for the Application of Nuclear Energy - INEP, University of Belgrade, Serbia \\ (Received $2^{\text {nd }}$ February 2011)
}

The aim of this study was to examine changes in some hormones concentrations in calves during the first 32 hours of neonatal life and to estimate their association with glycemia. Thyrty two Holstein breed calves were selected for the study. Blood samples were taken at 30,60 and 90 minutes postnatal. Calves received pooled colostrum: primary colostum (1.5 L, 2 hours after birth), secondary colostrum ( $2 \mathrm{~L}, 14$ hours after birth) and tertiary colostrum (2 L, 26 hours after birth). Blood samples were taken at hours 5,20 and 32 of neonatal life. Concentrations of glucose, insulin, cortisol, thyroid hormones and IGF-I and abundance of IGFBP-1, IGFBP-2 and IGFBP-3 were determined in the blood serum. The $T_{3} / T_{4}$ ratio was also calculated.

Calves were born hypoglycemic (glycemia was 2.56 \pm 1.05 $\mathrm{mmol} / \mathrm{L}$ at birth). Thereafter, glycemia significantly increased $(p<0.001)$ to $3.05 \pm 0.89 \mathrm{mmol} / \mathrm{L}$ at $\mathrm{min} 90$. Glucose concentration showed a further increase after colostrum intake and was significantly higher than at the initial value in all examined periods $(p<0.001)$. During the first 90 minutes of neonatal life insulinemia decreased significantly $(p<0.001)$ compared to initial value $(26.33 \pm 10.05 \mu / U / L)$ and it measured $18.66 \pm 5.56 \mu / \mathrm{U} / \mathrm{L}$ at min 90 . Cortisolemia was highest at minute 30 $(85.08 \pm 19.36 \mathrm{nmol} / \mathrm{L})$ and than decreased until the end of the experiment $(p<0.001)$ compared to initial values in samples obtained during the period of colostrum intake. A significantly high correlation was determined between glycemia and cortisolemia in all examined periods before the first colostrums intake $\left(r^{2}=0.854 ; p<0.01\right.$ at min 30 ; $r^{2}=0.742 ; p<0.01$ at $\min 60$ and $r^{2}=0.551 ; p<0.01$ at $\left.\min 90\right) . T_{4}$ concentrations significantly increased during the first 2 hours, while $T_{3}$ concentrations decreased, significantly from min 30 to min 90 postnatal $(p<0.05) . T_{3} / T_{4}$ ratio significantly increased during the first 2 hours of neonatal life. After first colostrum intake, concentrations of both hormones rose significantly compared to the initial level, but $T_{3} / T_{4}$ ratio did not change and maintained the value determined at minute 90. IGF1 concentrations significantly decreased during the first 2 postnatal hours. A significant positive correlation was observed between IGF-1 concentration and insulinemia $\left(r^{2}=0.463 ; p<0.05\right.$ at $\min 30, r^{2}=0.662$; 
$p<0.01$ at $\min 60$ and $r^{2}=0.583 ; p<0.01$ at $\min 90$ ). IGFBP-3 abundance significantly decreased, while IGFBP-1 significantly increased in this period. IGFBP-2 abundance was highest at birth. Results presented in this study indicate that the increase in glucose concentration during the first 2 hours of neonatal life, before the first colostrum intake is mainly the result of increased activity of the adrenal cortex in cortisol secretion and extrathyroidal tissue thus providing sufficient triiodothyronine. Immaturity of mechanisms responsible for insulin secretion provides the dominance of catabolic processes. Changes of the IGF system provide a rise of glucose concentration and establishment of energy balance.

Key words: glycemia, hormonal status, IGF system, neonatal calves

\section{INTRODUCTION}

The first $24 \mathrm{~h}$ in newborn calves are the most critical ones for survival. Energy demands are high and physiological adjustments to the environment are great. Therefore, it is important to study those adjustments to obtain valiable information for introducing adequate feeding regime, defending neonatal diseases and improving production and to offer experimental data of animals for enriching comparative and development physiology. As glucose is the crucial energy fuel for organisms, development of homeostatic control mechanisms that maintain glucose level in the physiological range are of great importance.

Neonatal calves are born hypoglycemic Oltner and Breglund (1982) reported that calves are born hypoglycemic and this finding was recently confirmed by Kirovski et al. (2008) and Steinhoff-Wagner et al. (2011). Before and shortly after birth circulating concentrations of glucagon and catecholamine increase and concentration of insulin decreases (Mao et al., 1994). Decreased insulin/glucagon ration stimulates glygogenolisis in the liver (Swenne et al., 1994). Corticosteroids, additionally, stimulate the increase of circulating glucose mainly by impaired peripheral insulin-dependent glucose utilization (Scheuer et al., 2006). There is no consistent literature data related to thyroid hormone concentrations immediately after birth (Davicco et al., 1982; Stojić et al., 2002; Kirovski et al., 2008). That is probably due to the fact that many factors, including enviromental temperature have effects on thyroid hormones concentrations. IGF 1 concentration declines after birth (Kirovski et al., 2002). A limited number of studies describes changes of concentrations of insulin-like growth factor binding proteins shortly after birth. Skaar and coworkers (1994) showed that the concentration of IGFBP-3 is higher than IGFBP-2 and IGFBP-1 immediately after birth in neonatal calves. This being opposite to most other animals and humans (Baxter and Martin, 1986; Lee et al., 1991; Owens et al., 1991). Changes in IGFBP ratios after parturition may influence glucose metabolism (Murphy, 2003). In humans, hypoglycemia with hyperinsulinemia is coupled with a decrease of IGFBP-3 concentration and increase of IGFBP-1 concentration (Collett-Solberg 
and Cohen, 1996). Decreased IGFBP-3/IGFBP-1 ratio enables IGF-1 to pass though the capillary walls into the extracellular space. All of these changes in hormone concentrations immediately after birth, before colostrum intake, are important for glucose homeostasis. Calves are born with glycogen reserves in the liver. Since glycogen capacity in newborn calves is limited, mechanisms that increase glucose concentrations after birth through glycogenolisis may keep glycemia in the physiological range during the first 2 to 4 hours of postnatal life (Edwards and Silver, 1969). After that, circulating glucose concentrations are maintained only by an additional supply of glucose i.e. by providing colostrum to newborn calves. Colostrum contain carbohydrates, fats, proteins, peptides, minerals, vitamins, hormones, growth factors, cytokines, enzymes, polyamines and nucleotides in different amounts than mature milk (Blum and Hammon, 2000). Colostrum is richer in fat, but lower in carbohydrate than mature milk. Since carbohydrate supply from colostrum is not sufficient to cover glucose utilization, the newborn is still dependent on its own ability to produce glucose to meet the needs of the growing animal. Colostrum intake stimulates B cells of the pancreas in newborn calves to produce insulin (Hammon and Blum, 1998). It is an open question if the endocrine pancreas is completely developed in newborns and if the utilization of glucose in peripheral tissue of newborn calves is same as in adult cattle.

The aim of this study was to investigate the interrelationship between glycemia, concentrations of some hormones and IGF system in newborn calves.

\section{MATERIAL AND METHODS}

\section{Calves}

Immidiatelly after birth, 32 calves (24 females and 8 males; Holstein-Friesian breed) were chosen and placed in individual boxes in a byre where the temperature ranged from 15 to $20^{\circ} \mathrm{C}$. All calves were born within a 4-week period. Average birth weight was $38.5 \pm 2.3 \mathrm{~kg}$ with no significant difference $(p>0.05)$ between the males $(39.7 \pm 1.8 \mathrm{~kg})$ and females $(38.1 \pm 2.3 \mathrm{~kg})$.

\section{Colostrum feeding}

Pools of colostrum were prepared for the first three feedings. Primary colostrum was taken up to $1 \mathrm{wk}$ in advance from cows 2 to $2.5 \mathrm{~h}$ after calving; secondary colostrum obtained at $14 \mathrm{~h}$ after calving; and tertiary colostrum obtained at $26 \mathrm{~h}$ after calving. Calves received $1.5 \mathrm{~L}$ of first colostum 2 hours after birth $(28.0 \pm 2.29 \%$ dry matter), $2 \mathrm{~L}$ of second colostrum 14 hours after birth (18.2 $\pm 1.78 \%$ dry matter) and $2 \mathrm{~L}$ of third colostrum 26 hours postnatally (15.9 $\pm 1.44 \%$ dry matter).

\section{Blood samples}

Blood samples were taken by jugular vein puncture, three times before colostrum feeding (minutes 30, 60 and 90 of postnatal life) and at 5, 20 and 32 hours postnatally. The obtained samples were placed into tubes and allowed to clot spontaneously at room temperature. The serum was decanted, centrifuged at 
$3000 \mathrm{~g}$, portioned into aliquots of $1.5 \mathrm{~mL}$, and stored in polypropylene microtubes at $20^{\circ} \mathrm{C}$ until analysis.

\section{Laboratory methods}

Glucose was measured spectrophotometrically using kits from HoffmanLaRoche (Basle, Switzerland) and an automatic analyzer (Secomam CE, BP 106; Secoman, France). Concentrations of insulin, IGF-I, cortisol, triiodothyronine $\left(\mathrm{T}_{3}\right)$ and thyroxine $\left(T_{4}\right)$ in sera were measured by radioimmunoassay (RIA; INEPZemun, Serbia). Intra-assay coefficients of variation (CV) ranged from $3.1 \%$ to $7.2 \%$. Assays were performed in duplicate and samples were analyzed within the same assay run.

For the IGF-I RIA, binding proteins were removed by acidethanol treatment followed by cryoprecipitation (Breier et al., 1991).

The IGFBP patterns in sera were characterized by sodium dodecyl sulphate - polyacrylamide gel electrophoresis (SDS-PAGE) and ligand-affinity blotting (Hossenlopp et al., 1986). Proteins were electrotransferred to nitrocellulose membrane $(0.45 \mathrm{~mm}$, Schleicher and Schuell), followed by autoradiography after incubation with ${ }^{125}$ IGF-I (specific activity: $36 \mathrm{MBq} / \mathrm{nmol}$ ). Protein bands were putatively identified according to the mobility of reference standards: bovine serum albumin (BSA, $66 \mathrm{kDa})$, ovalbumin (45 kDa), glyceraldehyde-3-phosphate dehydrogenase (36 kDa), carbonic anhydrase (29 kDa), and chymotrypsin $(24 \mathrm{kDa})$. Autoradiographic band patterns were quantitated using the GlycoBandScan program (Version 5, 1998; PROZYME, San Leandro, California, USA). The abundance of IGFBP bands was expressed in arbitrary densitometric units (ADU).

\section{RESULTS AND DISCUSSION}

The average concentrations of glucose of calves during the first 32 hours after birth are shown in Figure 1.

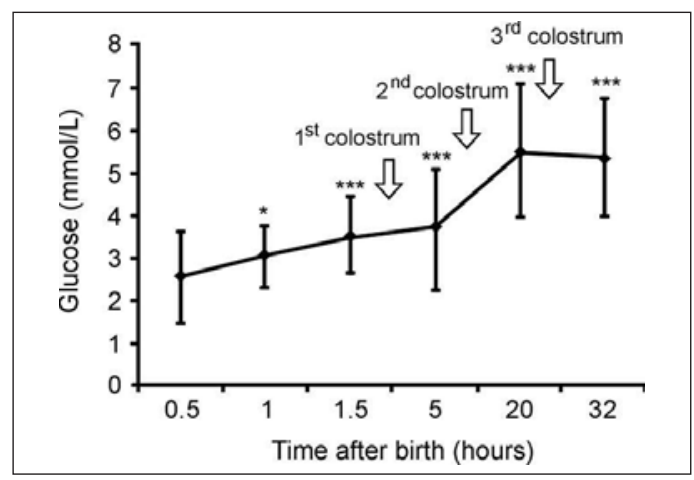

Figure 1. Changes of blood glucose concentrations during the first hours after birth in calves (mean $\pm S D, n=32$ ). ${ }^{*} p<0.05 ;{ }^{* \star *} p<0.001$ compared with value at birth 
Concentration of glucose at birth was $2.56 \pm 1.05 \mathrm{mmol} / \mathrm{L}$. Glycemia increased to $3.03 \pm 0.72 \mathrm{mmol} / \mathrm{L}$ at 60 min after birth $(p<0.05 \mathrm{compared}$ to initial level) and $3.5 \pm 0.89 \mathrm{mmol} / \mathrm{L}$ at $90 \mathrm{~min}$ after birth $(p<0.001$ compared to initial level). The abrupt increase of glucose within the first 2 hours of neonatal life, before colostrum intake, indicates changes in hormonal control that provide the rise of glucose in the blood. Further increase of glucose, after colostrum intake, are expectable and are caused by suckling of colostrum rich in lactose (SteinhoffWagner et al., 2011). Three hours after intake of the first colostrum glycemia was $3.70 \pm 1.43 \mathrm{mmol} / \mathrm{L}(p<0.001 \mathrm{compared}$ to the initial level). Six hours after the intake of second colostrum glycemia was $5.52 \pm 1.54 \mathrm{mmol} / \mathrm{L} \quad(p<0.001$ compared to initial level), while 32 hours postnatally it was $5.32 \pm 1.39 \mathrm{mmol} / \mathrm{L}$ $(p<0.001$ compared to initial level). Since in this study colostrum was offered to calves at the recommended time after birth ( 2 to 4 hours postnatally), there was no decline of glucose concentration before colostral intake which was previously observed by some authors (Grongnet et al., 1985; Hadorn et al., 1997). Our work indicates that the optimal time for first colostrum intake by calves is at hour 2 of neonatal life. Namely, if colostrum is offered to calves at this time, there will be no decline in glucose concentration and it will be maintained in the physiological range (Figure 1). It is well known that colostrum provides nutrients, and also passive immunity and growth factors that are essential for good adaptation of neonatal calf to changeable environment (Blum and Hammon, 2000).

Serum levels of insulin and cortisol are presented in Figure 2.
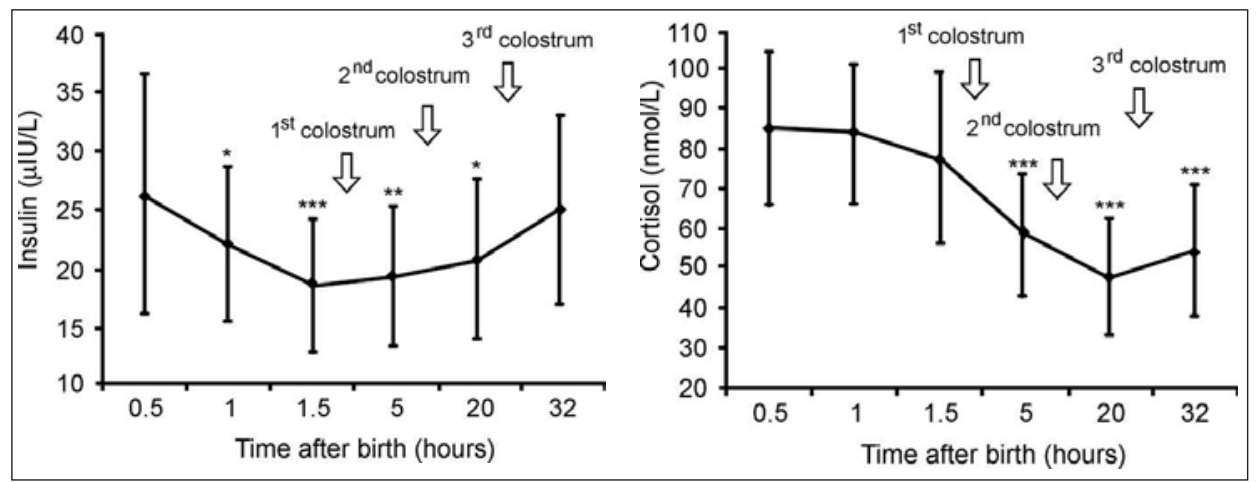

Figure 2. Changes of blood serum insulin and cortisol concentrations during the first hours after birth in calves (mean $\pm S D, n=32$ ). ${ }^{*} p<0.05 ;{ }^{* *} p<0.01 ;{ }^{* * *} p<0.001$ compared with value at birth

Serum levels of insulin decline during the first 2 hours of neonatal life i.e. before colostrum intake. Initial insulinemia was $26.33 \pm 10.05 \mu \mathrm{lU} / \mathrm{L}$. Thirty minutes later glycemia significantly decreased $(p<0.05)$ to $22.07 \pm 6.54 \mu \mathrm{IU} / \mathrm{L}$. Lowest insulin concentration was determined 90 minutes posnatally $(18.66 \pm$ $5.56 \mu \mathrm{IU} / \mathrm{L} ; \mathrm{p}<0.001$ compared to initial level). Since insulin is an anabolic 
hormone, one of the most important adaptations to the state of starvation is the decrease of insulin concentration (Blum and Hammon, 1999). Lower insulin concentration in the circulation provides increased activity of catabolic proceses, like glycogenolisis, and keeps circulating glucose within the physiological range. Calves are born with glycogen stored in the liver. Glycogenolisis is stimulated not only by decreased insulin concentration, but also increased glucagon concentration (Mayor and Cuezva, 1985). After intake of first colostrum insulin concentration increased, but not significantly since it was still lower than at the initial level. Insulinemia was $19.36 \pm 5.89 \mu \mathrm{IU} / \mathrm{L}$ at hour $5(p<0.01$ compared to the initial value) and $20.77 \pm 6.69 \mu \mathrm{lU} / \mathrm{L}$ at hour 20 ( $p<0.05$ compared to initial value). Additionally, there was no statistically significant difference between insulin concentration at 90 minutes and 5 hours $(p>0.05)$ and 20 hours $(p>0.05)$ of postnatal life. After birth (32 hours), insulinemia was $25.12 \pm 7.97 \mu \mathrm{lU} / \mathrm{L}$, similar to the initial insulin concentration. Insulin concentration increases after intake of colostrum due to absorbed glucose which originated from digested lactose in the small intestine of calves (Steinhoff-Wagner et al., 2011). Glucose stimulates B cells of the pancreas to produce insulin. Ingested colostrum increase the secretion of many gastrointestinal hormones such as gastrin, secretin, cholecystokinin (CCK), gastric inhibitory polypeptide (GIP) and vasoactive intestinal peptide (VIP) that stimulate the $B$ cells of pancreatic islets to syntetase and release insulin (Lavine and Attie, 2010). Nevertheless, insulin concentration at hours 5 and 20 did not significantly increase. It indicates that insulin secretory mechanisms are not fully developed in newborns. Since colostrum is rich in insulin and intact insulin molecules can be absorbed during the first 24 hours of neonatal life (Kirovski et al., 2008), it is possible that the absorbed insulin compensates endogen insulin deficiency.

Cortisol concentration was high at birth $(85.08 \pm 19.36 \mathrm{nmol} / \mathrm{L})$, probably due to the stimulation of parturition stress on the adrenal cortex (Jacob et al., 2001). Thereafter, cortisol concentration decreased gradually to $83.95 \pm$ $17.59 \mathrm{nmol} / \mathrm{L}$ at $\min 60$ and $77.77 \pm 21.06 \mathrm{nmol} / \mathrm{L}$ at $\mathrm{min} 90$ postnatal. These results are similar to studies in earlier reports (Jacob et al., 2001; Stojić et al., 2002). There was a significant correlation between cortisol and glucose concentrations at $30 \min \left(r^{2}=0.854 ; p<0.01\right), 60 \min \left(r^{2}=0.742 ; p<0.01\right)$ and 90 $\min \left(r^{2}=0.551 ; p<0.01\right)$. This result is in accordance with the results of Massip (1981). Although earlier studies explained this relationship through the effect of cortisol on gluconeogenesis, Scheuer and coworkers (2006) found that the increased plasma glucose concentrations, however, are not associated with the stimulation of hepatic gluconeogenic enzyme activities, but with impaired peripheral insulin-dependent glucose utilization. Decline in cortisol concentration continues after intake of colostrums and was $58.09 \pm 15.57 \mathrm{nmol} / \mathrm{L}$ at hour 5 $(p<0.001$ compared to initial level), $47.49 \pm 15.02 \mathrm{nmol} / \mathrm{L}$ at hour $20(p<0.001$ compared to initial level). Cortisolemia was $54.14 \pm 16.65 \mathrm{nmol} / \mathrm{L}$ at hour 32 $(p<0.001$ compared to initial level). These results are in accordance with Stojić et al. (2002), and Bittrich et al. (2002).

3.

Serum levels of $T_{3}$ and $T_{4}$ and calculated $T_{3} / T_{4}$ index are presented in Figure 
Acta Veterinaria (Beograd), Vol. 61, No. 4, 349-361, 2011.

Kirovski Danijela et al.: Hormonal status and regulation of glycemia in neonatal calves during the first hours of postnatal life

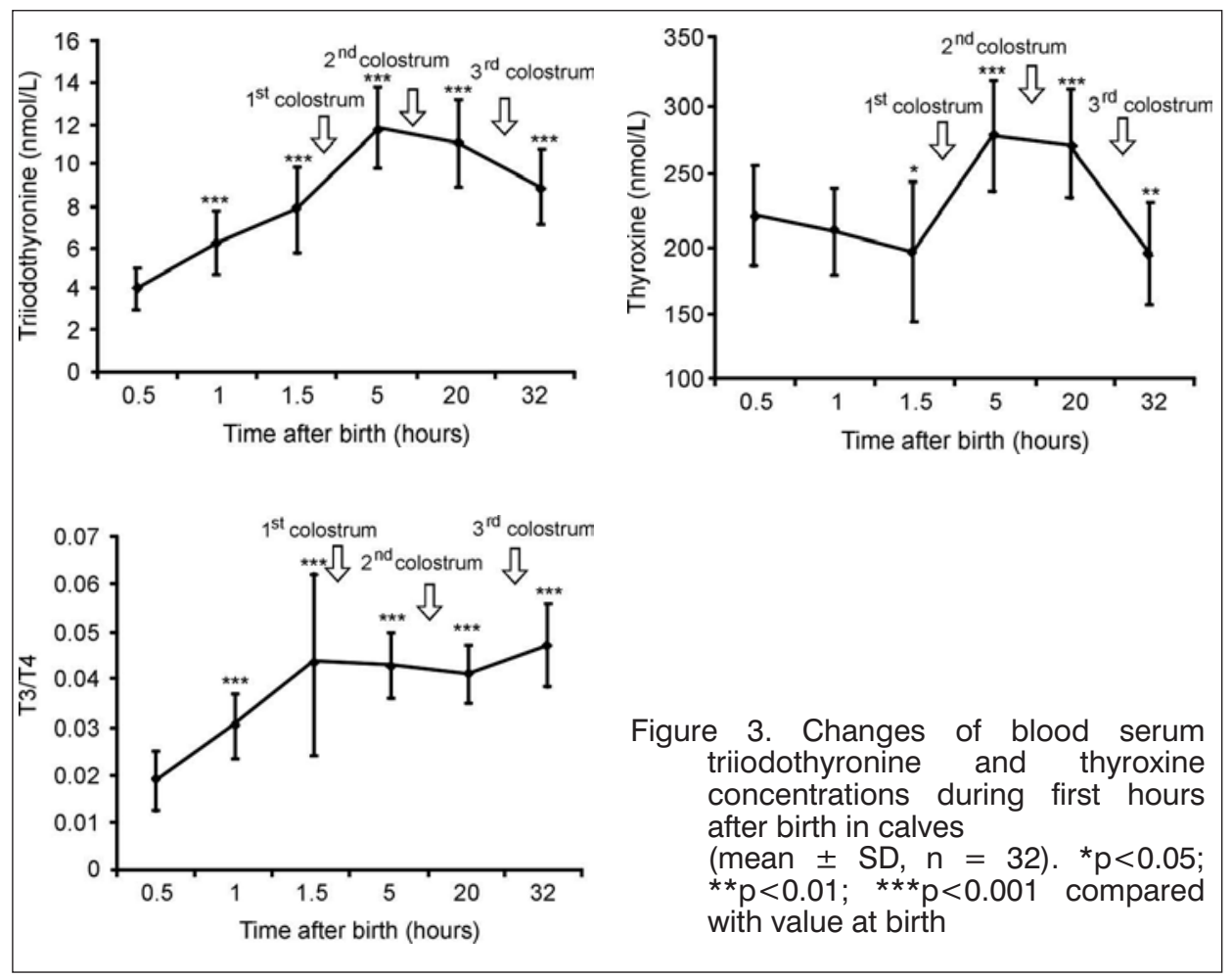

An obviously increasing tendency of $T_{3}$ and decreasing tendency for $T_{4}$ within the first 2 hours of neonatal life, and their increase after intake of colostrums was found in this study. There is inconsistency in literature data related to the concentration of thyroid hormones in newborn calves (Davicco et al., 1982; Stojić et al., 2002; Kirovski et al., 2008). This can be explained by the fact that the concentrations of these hormones are under a strong influence of environmental factors. Calves born during the winter period had higher concentrations of thyroid hormones than calves born in other seasons, since the cold environment stimulates the thyroid gland to synthesize and secrete more hormones in neonatal animals after parturition (Stanko et al., 1991). All calves involved in our study were born in September when the average environmental temperatures were from 15 to $20^{\circ} \mathrm{C}$. Thyroid concentrations within the first 2 hours were $3.99 \pm 1.06 \mathrm{nmol} / \mathrm{L}$ for $\mathrm{T}_{3}$ and $221.56 \pm 39.56 \mathrm{nmol} / \mathrm{L}$ for $\mathrm{T}_{4}$ at $\min 30,6.23 \pm 1.51 \mathrm{nmol} / \mathrm{L}$ for $\mathrm{T}_{3}(\mathrm{p}<0.001$ compared to initial level) and $210.12 \pm 30.95 \mathrm{nmol} / \mathrm{L}$ for $\mathrm{T}_{4}$ at min 60 and $7.89 \pm$ $2.12 \mathrm{nmol} / \mathrm{L}$ for $\mathrm{T}_{3}(\mathrm{p}<0.001 \mathrm{compared}$ to initial level) and $196.05 \pm 49.92 \mathrm{nmol} / \mathrm{L}$ for $\mathrm{T}_{4}(\mathrm{p}<0.05$ compared to initial level) at min 90 . After the first and second feeding with colostrum $\mathrm{T}_{3}$ and $\mathrm{T}_{4}$ concentrations increased and thereafter decreased at hour 32 of postnatal life. Thyroid hormones concentrations were $11.74 \pm 1.90 \mathrm{nmol} / \mathrm{L}$ for $\mathrm{T}_{3}(\mathrm{p}<0.001$ compared to initial level) and $278.22 \pm$ $38.80 \mathrm{nmol} / \mathrm{L}$ for $\mathrm{T}_{4}(\mathrm{p}<0.001$ compared to initial level) at hour $5,11.05 \pm$ 
$2.13 \mathrm{nmol} / \mathrm{L}$ for $\mathrm{T}_{3}(p<0.001$ compared to initial level $)$ and $271.42 \pm 38.33 \mathrm{nmol} / \mathrm{L}$ for $\mathrm{T}_{4}\left(\mathrm{p}<0.001\right.$ compared to initial level) at hour 20 and $8.93 \pm 1.87 \mathrm{nmol} / \mathrm{L}$ for $\mathrm{T}_{3}$ $\left(p<0.001\right.$ compared to initial level) and $194.55 \pm 36.45 \mathrm{nmol} / \mathrm{L}$ for $\mathrm{T}_{4}(p<0.01$ compared to initial level) at hour 32 postnatal.

Good explanation concerning thyroid gland function may be provided using $T_{3} / T_{4}$ ratio (Šamanc et al., 2010). The $T_{3} / T_{4}$ ratio is a calculated weight units ratio that reflects thyroid gland function and the potential for action of these hormones on peripheral tissues. The thyroid gland produces mainly $T_{4}$, but also a small quantity of $T_{3}$. In the peripheral tissues the mostly inactive $T_{4}$ undergoes extrathyroidal enzymatic activation by $5^{\prime}$ deiodinase $\left(5^{\prime} \mathrm{D}\right)$ producing the much more potent $T_{3}$ (Bianco and Kim, 2006). Our results show that the $T_{3} / T_{4}$ ratio significantly increases after birth until colostral intake. Thereafter, $T_{3} / T_{4}$ ratio is maintained until 32 hours of postnatal life. These results indicate that activation of deiodinases in the peripheral tissues is higher during starvation in neonatal calves. When calf receives colostrum, energy balance is established and deiodinase activity decreases. That supports the earlier conclusion that colostrum should be offered to calves in the first 2 to 4 hours after birth.

Values obtained for the circulating components of the IGF system (IGF-1, IGFBP-1, IGFBP-2 and IGFBP-3) are presented in Figure 4.

IGF system in the neonates can be described by the concentration of IGF-1 and its binding proteins in the circulation (Blum and Hammon, 1999). Concentrations of IGF-1 in our study decline during the first 2 hours of postnatal life and are maintained at a significantly lower level than the initial one until hour 32 of neonatal life. Initial IGF-1 concentration was $20.95 \pm 4.12 \mathrm{nmol} / \mathrm{L}$ and decreased to $18.56 \pm 3.56 \mathrm{nmol} / \mathrm{L}(p<0.05$ compared to initial level) at $60 \mathrm{~min}$ and to $16.25 \pm 2.93 \mathrm{nmol} / \mathrm{L}(p<0.001$ compared to initial level) at $90 \mathrm{~min}$. After intake of colostrum IGF-1 concentrations were $16.25 \pm 2.93 \mathrm{nmol} / \mathrm{L}$ ( $p<0.001$ compared to initial level), $16.04 \pm 2.39 \mathrm{nmol} / \mathrm{L}(\mathrm{p}<0.001$ compared to initial level) and $17.63 \pm 2.48 \mathrm{nmol} / \mathrm{L}(p<0.001$ compared to initial level) for hours 5, 20 and 32 , respectively. Lower IGF-1 concentration is typical for the condition of negative energy balance. Hammon et al. (1997) showed that the somatotropic axis is not funcional in neonatal calves and that IGF-1 has a strong influence on metabolisam during the first few hours of neonatal life, before intake of colostrum. In the condition of negative energy balance i.e. starvation, the concentration of IGF-1 depends on the concentration of insulin in the circulation (Rabkin, 1997). Our results confirms this, since there is a significant correlation between IGF-1 and insulin concentrations during the first 2 hours of postnatal life. Correlation coefficients between insulinemia and IGF-1 concentration were $r^{2}=0.463$ $(p<0.05)$ for $30 \mathrm{~min}, r^{2}=0.662(p<0.01)$ for $60 \mathrm{~min}$ and $r^{2}=0.583(p<0.01)$ for 90 min postnatal.

Higher levels of circulating IGF-I are usually associated with increased amounts of IGFBP-3, which forms a large tertiary complex unable to pass though the capillary walls into the extracellular space and decreased amount of IGFBP-1 which allowed IGF-1 molecules to pass into the tissue (Lelbach et al., 2005). The described arrangement of IGF system components may be observed in our study at 30 min postnatally. Highest abundance of of IGFBP-3 (47.09 $\pm 4.75 \mathrm{ADU} / 10 \mu \mathrm{L})$ 
Acta Veterinaria (Beograd), Vol. 61, No. 4, 349-361, 2011.

Kirovski Danijela et al.: Hormonal status and regulation of glycemia in neonatal calves during the first hours of postnatal life

and lowest abundance of IGFBP-1 (22.05 $\pm 4.86 \mathrm{ADU} / 10 \mu \mathrm{L})$ was observed at 30 min, compared to other time periods. Additionally, highest abundance of IGFBP-2 was observed immediately after birth $(25.81 \pm 3.79 \mathrm{ADU} / 10 \mu \mathrm{L})$ which is in accordance to the stress reaction characterized by increased concentration of IGFBP-2 (Nikolić et al., 2003). After birth, the abundance of IGFBP-3 significantly decreased to $44.01 \pm 3.44 \mathrm{ADU} / 10 \mu \mathrm{L}$ at $60 \mathrm{~min}(\mathrm{p}<0.05$ compared to initial value) and $41.72 \pm 4.97 \mathrm{ADU} / 10 \mu \mathrm{L}$ at $90 \mathrm{~min}$ ( $p<0.01$ compared to initial value) and maintained low after intake of colostrum. IGFBP-3 abundance was $43.14 \pm$ $4.98 \mathrm{ADU} / 10 \mu \mathrm{L}$ at 5 hours $(\mathrm{p}<0.05$ compared to initial value), $44.66 \pm$ $5.06 \mathrm{ADU} / 10 \mu \mathrm{L}$ at 20 hours and $47.04 \pm 3.43 \mathrm{ADU} / 10 \mu \mathrm{L}$ at 32 hours. Our results are in agreement with Hammon et al. (2003) and Onsouka et al. (2004). Hammon et al. (2000) showed that delaying colostrum feeding from 2 to 12 or $24 \mathrm{~h}$ after birth led to decreased plasma IGF-I concentrations associated with decreased IGFBP3 concentration. IGFBP-2 abundance decreased after birth to $24.46 \pm$ $3.55 \mathrm{ADU} / 10 \mu \mathrm{L}$ at $60 \mathrm{~min}$ and to $22.69 \pm 4.25 \mathrm{ADU} / 10 \mu \mathrm{L}$ at 90 min postnatally $(p<0.05$ compared to initial value). After intake of colostrum, IGFBP-2 abundance

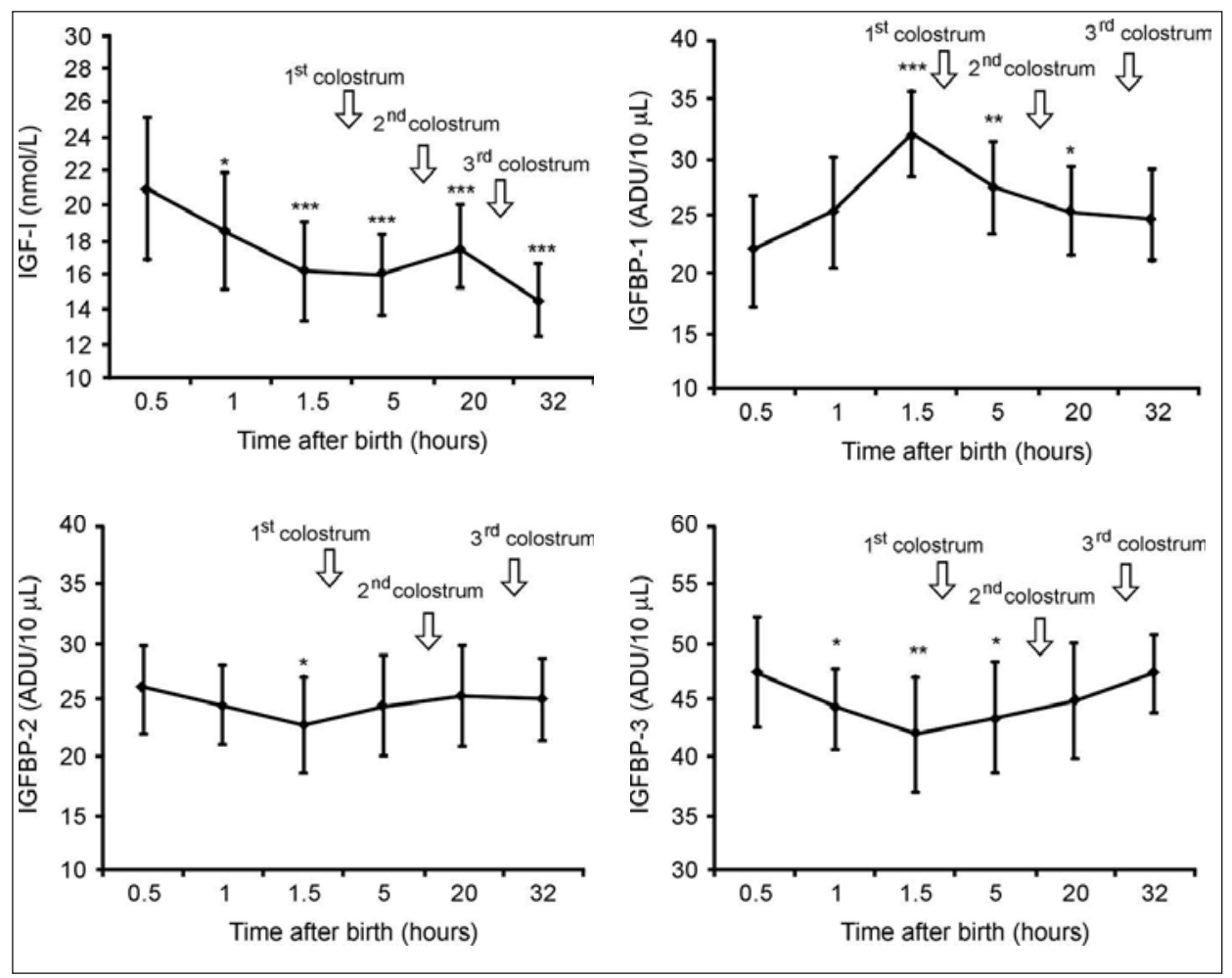

Figure 4. Changes of blood serum IGF-I concentrations (mean $\pm S D, n=32$ ) and IGFBP-1, IGFBP-2 and IGFBP-3 abundance (mean $\pm \mathrm{SD}, \mathrm{n}=16$ ) during the first hours after birth in calves. ${ }^{*} p<0.05 ;{ }^{*} p<0.01 ;{ }^{* * *} p<0.001$ compared with value at birth 
increased, but not significantly to $24.45 \pm 4.44 \mathrm{ADU} / 10 \mu \mathrm{L}$ at 5 hours, to $25.31 \pm$ $4.25 \mathrm{ADU} / 10 \mu \mathrm{L}$ at 20 hours and to $25.16 \pm 3.57 \mathrm{ADU} / 10 \mu \mathrm{L}$ at 32 hours. Abundance of IGFBP-1 increased during the first 2 hours of neonatal life from the initial value $(22.04 \pm 4.86 \mathrm{ADU} / 10 \mu \mathrm{L})$ to $25.26 \pm 4.77 \mathrm{ADU} / 10 \mu \mathrm{L}$ at $60 \mathrm{~min}$ and $31.99 \pm 3.76 \mathrm{ADU} / 10 \mu \mathrm{L}$ at 90 min postnatally ( $<0.001$ compared to initial value) The presence of a positive relationship of insulin and IGFBP-1 in our work is in accordance with the well-known acute effect of insulin on its synthesis (Goswami et al., 1994). IGFBP-1 abundance decreases after intake of colostrum but remains significantly higher then the initial value at 5 hours $(27.28 \pm 4.15 \mathrm{ADU} / 10 \mu \mathrm{L}$; $p<0.01)$ and 20 hours $(25.30 \pm 3.90 \mathrm{ADU} / 10 \mu \mathrm{L} ; \mathrm{p}<0.05)$. At hour 32 of neonatal life IGFBP-1 abundance was $24.93 \pm 3.86 \mathrm{ADU} / 10 \mu \mathrm{L}$.

In conclusion, immediately after birth the vigorous activity of the adrenal cortex in cortisol secretion and extrathyroidal tissue in providing a sufficient level of triiodothyronine play a crutial role in the mobilization of energy reserves, promotion of catabolism and subsequent rise in glucose concentration. Additionally, immaturity of the somatotropic axis and mechanisms responsible for insulin secretion provide dominance of catabolic processes during this period of neonatal life.

\section{ACKNOWLEDGEMENTS:}

This work was supported by Ministry of science and technology, Republic of Serbia, Project Grant No 46002 .

Address for correspondence:

Danijela Kirovski, DVM, PhD

Department of Physiology and Biochemistry

Faculty of Veterinary Medicine

University of Belgrade

Bulevar oslobodjenja 18

11000 Belgrade, Serbia

E-mail: dani@vet.bg.ac.rs

\section{REFERENCES}

1. Baxter RC, Martin JL, 1986, Radioimmunoassay of growth hormone-dependent insulin-like growth factor binding protein in human plasma, $J$ Clin Invest, 78, 1504-12.

2. Bianco AC, Kim BW, 2006, Deiodinases: implications of local control of thyroid hormone action, $J$ Clin Invest, 116, 2571-9.

3. Bittrich S, Morel C, Philipona C, Zbinden Y, Hammon HM, Blum JW, 2002, Physiological traits in preterm calves during their first week of life, $J$ Anim Physiol and Anim Nutr, 86, 185-98.

4. Blum JW, Hammon H, 1999, Endocrine and metabolic aspects in milk-fed calves, Dom Anim Endocrinol, 17, 219-30.

5. Blum JW, Hammon HM, 2000, Bovine colostrum: more than just an immunoglobulin supplier, Schwizs Arch Tierheokd, 142, 221-8.

6. Breier BH, Gallaher BW, Gluckman PD, 1991, Radioimmunoassay for insulin-like growth factor-l: Solutions to some potential problems and pitfalls, J Endocrinol, 28, 347-57.

7. Collett-Solberg PF, Cohen $P, 1996$, The role of the insulin-like growth factor binding proteins and the IGFBP proteases in modulating IGF action, Endocrinol Metab Clin North Am, 25, 591-614.

8. Davicco MJ, Vigouroux E, Dardillat C, Barlet JP, 1982, Thyroxine, tri-iodothyronine and iodide in different breeds of newborn calves, Reprod Nutr Dev, 22, 355-62. 
9. Edwards AW, Silver M, 1969, The glucogenolytic response to stimulation of the splanhnic nerves in adrenalectomized calves, J Physiol, 211, 109-13.

10. Goswami R, Lacson R, Yang E, Sam R, Unterman T, 1994, Functional analysis of glucocorticoid and insulin response sequences in the rat insulin-like growth factor-binding protein-1 promotor, Endocrinology, 134, 736-43.

11. Grongnet JF, Grongnet-Pinchon E, Witowski A, 1985, Neonatal levels in plasma thyroxine in male and female calves fed a colostrums or immunoglobulin diet and fasted for the first 28 hours of life, Reprod Nutr Dev, 25, 537-43.

12. Haddorn U, Hammon H, Bruckmaier RM, Blum JW, 1997, Delaying colostrums intake by one day has important effects on metabolic traits and on gastrointestinal and metabolic hormones in neonatal calves, J Nutr, 127, 2011-23.

13. Hammon HM, Blum JW, 1997, The somatotropic axis in neonatal calves can be modulated by nutrition, growth hormone and long-R3-IGF-I, Am J Physiol, 273, E130-8.

14. Hammon HM, Blum JW, 1998, Metabolic and endocrine traits of neonatal calves are influenced by feeding colostrums for different durations or only milk replacer, J Nutr, 128, 624-32.

15. Hammon HM, Zanker IA, Blum JW, 2000, Delayed colostrum feeding affects IGF-I and insulin plasma concentrations in neonatal calves, J Dairy Sci, 83, 85-2.

16. Hammon HM, Zbinden Y, Sauerwein H, Breier BH, Blum JW, Donkin SS, 2003, The response of hepatic insulin-like growth factor system to growth hormone and dexamethasone in calves, $J$ Endocrinol, 179, 427-35.

17. Hossenlopp P, Seurin D, Segovia-Quinson B, Hardouin S, Binoux M, 1986, Analysis of serum insulin-like growth hormone binding proteins using Western blotting: Use of the method for titration of the binding proteins and competitive binding studies, Anal Chem, 154, 138-43.

18. Jacob SK, Ramnath V, Philomina PT, Raghunandhanan KV, Kannan A, 2001, Assessment of physiological stress in peruparturient cows and neonatal calves, Indian J Physiol Pharmacol, 45, 233-8.

19. Kirovski D, Lazarević M, Baričević-Jones I, Nedić O, Masnikosa R, Nikolić JA, 2008, Effect of peroral insulin and glucose on circulating insulin-like growth factor-1, its binding proteins and thyroid hormones in neonatal calves, Can J Vet Res, 72, 253-8.

20. Kirovski D, Stojić V, Nikolić JA, 2002, Serum levels of insulin-like growth factor-I and total protein in newborn calves offered different amounts of colostrums, Acta Vet (Belgrade), 52, 285-98.

21. Lavine JA, Attie AD, 2010, Gastrointestinal hormones and the regulation of B-cell mass, Ann N Acad Sci, 1212, 41-58.

22. Lee CY, Bazer FW, Etherton TD, Simmen FA, 1991, Ontogeny of insulin-like growth factors (IGF-I and IGF-11) and IGF-binding proteins in porcine serum during fetal and postnatal development, Endocrinology, 128, 2336-44.

23. Lelbach A, Muzes G, Feher J, 2005, The insulin-like growth factor system: IGFs, IGF-binding proteins and IGFBP-proteases, Acta Physiol Hung, 92, 97-107.

24. Mao XZ, Li ZL, Zhu ZK, Qin WL, 1994, The development changes and correlations of some blood hormone leveles and immune indexes during the postnatal period in neonatal calves, $J$ Vet Med A, 41, 405-12.

25. Massip A, 1980, Relationship between $\mathrm{pH}$, plasma cortisol and glucose concentrations in the calf at birth, Br Vet J, 136, 597-601.

26. Mayor F, Cuezva JM, 1985, Hormonal and metabolic changes in te perinatal period, Bio Neonate, 48, 185-96.

27. Murphy LJ, 2003, The role of insulin-like growth factors and their binding protein in glucose homeostasis, Exp Diabesity Res, 4, 213-24.

28. Nikolić JA, Kulesar M, Kátai L, Nedić O, Jánosi S, Huszenicza G, 2003, Periparturient endocrine and metabolic changes in healthy cows and cows affected with mastitis, J Vet Med A Physiol Pathol Clin Med, 50, 22-9.

29. Oltner R, Berglund B, 1982, Blood levels of haemoglobin, leukocytes, glucose, urea, creatinin, calcium, magnesium and inorganic phosphorus in dairy calves from birth to 12 weeks of age, Swedish J Agr Res, 12, 23-8. 
30. Ontsouka EC, Hammon HM, Blum JW, 2004, Expression of insulin-like growth factors (IGF)-1 and 2, IGF-binding proteins-2 and -3, and receptor for growth hormone, IGF type-1 and -2 and insulin in the gastrointestinal tract of neonatal calves, Growth Factors, 22, 63-9.

31. Owens PC, Conlon MA, Campbell RG, Johnson RJ, King R, Ballard FJ, 1991, Developmental changes in growth hormone, insulin-like growth factors (IGF-I and IGF-11) and IGF-binding proteins in plasma of young growing pigs, $J$ Endocrinol, 128, 439-47.

32. Rabkin R, 1997, Nutrient regulatin of insulin-like growth factor-I, Mineral Electrolyte Metab, 23, 15760.

33. Scheuer BH, Zbinden Y, Schneiter P, Tappy L, Blum JW, Hammon HM, 2006, Effects of colostrums feeding and glucocorticoid administration on insulin-dependent glucose metabolism in neonatal calves, Domest Anim Endocrinol, 31, 227-45.

34. Skaar TC, Baumrucker TC, Deaver DR, Blum JW, 1994, Diet effects and ontogeny of alterations of circulating insulin-like growth factor binding proteins in newborn dairy calves, J Anim Sci, 1994, 72, 421-7.

35. Stanko RL, Guthrie MJ, Randel RD, 1991, Response to environmental temperatures in Brahman calves during the first compared to the second day after birth, J Anim Sci, 69, 4419-27.

36. Steinhoff-Wagner J, Görs S, Junghans P, Bruckmajer RM, Kanitz E, Metges CC et al., 2011, Intestinal glucose absorption but not endogenous glucose production differs between colostrum- and formula-fed neonatal caves, $J$ Nutr, 141, 48-55.

37. Stojić V, Nikolić JA, Huszenicza Gy, Šamanc H, Gvozdić D, Kirovski D, 2002, Plasma levels of triiodothyronine, thyroxine and cortisol in newborn calves, Acta Vet (Belgrade), 52, 85-96.

38. Swenne I, Ewald U, Gustafsson J, Sandberg E, Östenson C-G, 1994, Inter-relationship between serum concentrations of glucose, glucagon and insulin during the first two days of life in healthy newborn, Acta Pediatr, 83, 915-9.

39. Šamanc H, Stojić V, Kirovski D, Jovanović M, Cernescu H, Vujanac I, 2010, Thyroid hormones concentrations during the mid-dry period: an early indicator of fatty liver in Holstein - Friesian dairy cows, J Thyroid Res, ID 897602.

\title{
HORMONALNI STATUS I REGULACIJA GLIKEMIJE KOD NOVOROĐENE TELADI TOKOM PRVIH SATI POSTNATALNOG ŽIVOTA
}

\author{
KIROVSKI DANIJELA, LAZAREVIĆ M, STOJIĆ V, ŠAMANC H, VUJANAC I, \\ PRODANOVIĆ R, NEDIĆ OLGICA i MASNIKOSA ROMANA
}

\section{SADRŽAJ}

Cilj ovog rada je bio da se ispitaju promene koncentracije pojedinih hormona kod novorođene teladi u prvim satima neonatalnog života i utvrdi njihov uticaj na glikemiju. Odabrana su 32 novorođena teleta Holštajn rase kojima je 30, 60. i 90. minuta postnatalnog života uzeta krv. Telad su bila napajana pulovima kolostruma. Pul primarnog kolostruma davan je u količinama od po 1,5 litar 2 sata nakon rođenja, dok su pulovi sekundarnog i tercijarnog kolostruma davani 12, odnosno 24 sata kasnije, u količinama od po 2 litra. Tokom perioda kolostralnog napoja, teladi je uzorkovana krv 5, 20 i 32. sata nakon rođenja. U uzorcima krvi određivana je koncentracija glukoze, insulina, kortizola, tireoidnih hormona i IGF-I, 
Acta Veterinaria (Beograd), Vol. 61, No. 4, 349-361, 2011.

Kirovski Danijela et al.: Hormonal status and regulation of glycemia

in neonatal calves during the first hours of postnatal life

kao i zastupljenost IGFBP-1, IGFBP-2 i IGFBP-3. Takođe je obračunat indeks konverzije $\mathrm{T}_{3}$ u $\mathrm{T}_{4}$.

Telad su bila rođena u stanju hipoglikemije (koncentracija glukoze na rođenju je iznosila 2,56 $\pm 1,05 \mathrm{mmol} / \mathrm{l}$ ). Nakon toga, glikemija je značajno porasla $(p<0,001)$ do $3,05 \pm 0,89 \mathrm{mmol} / \mathrm{l}(90$. minut). Porast koncentracije glukoze je nastavljen i nakon unosa kolostruma, tako da je glikemija u svim ispitivanim uzorcima bila značajno veća u odnosu na početnu vrednost $(p<0,001)$. Tokom prvih $90 \mathrm{mi}-$ nuta neonatalnog života, koncentracija insulina se značajno smanjivala $(p<$ $0,001)$ u odnosu na početnu vrednost $(26,33 \pm 10,05 \mu \mathrm{lU} / \mathrm{I})$ tako da je 90 . minuta postnatalnog života bila 18,66 $\pm 5,56 \mu \mathrm{IU} / \mathrm{l}$. Porast insulinemije nakon unosa kolostruma nije bio značajan u odnosu na vrednost određenu 90. minuta. Koncentracija kortizola je bila najviša 30 minuta nakon teljenja $(85,08 \pm 19,36 \mathrm{nmol} / \mathrm{l})$ a zatim je opadala do kraja perioda ispitivanja i to značajno $u$ odnosu na početnu vrednost $(p<0,001)$ u uzorcima dobijenim nakon unosa kolostruma. Visoka pozitivna korelacija je utvrđena između glikemije i kortizolemije u svim ispitivanim terminima pre kolostralnog napoja $\left(r^{2}=0,854\right.$ u 30. minutu; $r^{2}=0,742 \mathrm{u} 60$. minutu i $\mathrm{r}^{2}=0,551$ u 90 . minutu). Koncentracija $\mathrm{T}_{4}$ je značajno rasla tokom prva dva sata neonatalnog života, dok se koncentracija $T_{3}$ smanjila, značajno od 30 . do 90 . minuta neonatalnog života $(p<0,05)$. Konverzija $\mathrm{T}_{3}$ u $\mathrm{T}_{4}$ je značajno porasla tokom prva dva sata života. Nakon unosa kolostruma, koncentracija oba tireoidna hormona se povećavala (značajno u odnosu na početnu vrednost) a indeks konverzije se nije menjao, već se zadržao na vrednosti ustanovljenoj 90. minuta života. Koncentracija IGF-1 se značajno smanjivala tokom prva 2 sata neonatalnog života. Koncentracija IGF-1 je bila u visokoj pozitivnoj korelaciji sa insulinemijom $\left(\mathrm{r}^{2}=\right.$ 0,463 za 30. minut, $r^{2}=0,662$ za 60 . minut i $r^{2}=0,583$ za 90. minut). Zastupljenost IGFBP-3 se značajno smanjivala, dok se zastupljenost IGFBP-1 značajno povećavala u ovom periodu. Zastupljenost IGFBP-2 je bila najveća na rođenju. Rezultati prikazani u ovom radu ukazuju da je porast glikemije u prvim satima života, pre unosa kolostruma, prevashodno posledica pojačane aktivnsoti kore nadbubrega u sekreciji kortizola i dejodinaza u ekstratireoidnim tkivima koje obezbeđuju povećanu sintezu $T_{3}$. Sistemi odgovorni za sintezu insulina nisu potpuno funkcionalni u ovom periodu, omogućavajući prevagu kataboličkih u odnosu na anaboličke procese. Promene unutar IGF sistema omogućavaju porast glikemije i uspostavljanje energetske ravnoteže. 
